\title{
Autochthonous Chagas' disease in Santa Catarina State, Brazil: report of the first case of digestive tract involvement
}

\author{
Doença de Chagas autóctone no Estado de Santa Catarina, Brasil: \\ relato do primeiro caso de comprometimento do trato digestivo
}

\author{
Felipe Antonio Boff Maegawa', Ernesto Francisco Damerau', Ingrid Thais Beltrame-Botelho², \\ Aldemar Lopes ${ }^{1}$, Priscilla Emmanuelle-Machado², Mário Steindel ${ }^{2}$ \\ and Edmundo Carlos Grisard ${ }^{2}$
}

\begin{abstract}
We report the first case of digestive tract pathology (megaesophagus) determined by Trypanosoma cruzi infection in Santa Catarina State, southern Brazil. A 63-year- old female had presumptive clinical diagnosis of Chagas' disease, which was confirmed by imaging (endoscopy and esophagogram) and immunological methods. Further molecular diagnosis was carried out with esophagus and blood samples collected during corrective surgery. Polymerase chain reaction tested positive for Trypanosoma cruzi in both esophagus and buffy coat samples.

Key-words: Trypanosoma cruzi. Human Chagas disease. Santa Catarina State. Megaesophagus.

Resumo Relatamos neste artigo o primeiro caso de megaesôfago determinado por infecção pelo Trypanosoma cruzi no Estado de Santa Catarina, região sul do Brasil. Uma paciente de 63 anos de ídade com diagnóstico clínico presuntivo de doença de Chagas, apresentou exames de imagem (endoscopia e esofagograma) e imunológicos positivos. Além disso, foi realizado diagnóstico molecular com amostras de esôfago e sangue coletadas durante a cirurgia corretiva. A reação em cadeia da polimerase apresentou-se positiva para Trypanosoma cruzi nas amostras de esôfago e no creme leucocitário.
\end{abstract}

Palavras-chaves: Trypanosoma cruzi. Doença de Chagas humana. Estado de Santa Catarina. Megaesôfago.

Chagas' disease affects around 18-20 million people in Central and South America. Moreover, $25 \%$ of the populations living in these areas are nowadays under high transmission risk ${ }^{13}$. Along with vector transmission, congenital and transfusional infection still occurs in several countries ${ }^{10}$. Studies on Trypanosoma cruzi sylvatic transmission cycle in Santa Catarina have pointed out that socio-economical and biological factors, such as the absence of domiciliated triatomine species, had major influence on the absence of $T$. cruzi domestic cycle ${ }^{211}$. The prevalence revealed by the national inquiry for Chagas disease $(7.6 \%$ up to $41.3 \%$ ) in distinct municipalities of the Santa Catarina State were not confirmed by other authors ${ }^{9}$.

Considered to be a nonendemic area for human Chagas' disease, only four autochthonous cases of human Chagas' disease have been reported in the State of Santa Catarina in southern Brazil and which only corresponded to the cardiac form of the disease ${ }^{5}$. In this work we present clinical, epidemiological, immunological, parasitological and molecular findings of the first case of megaesophagus due to Chagas' disease in the State of Santa Catarina, southern Brazil.

\section{CASE REPORT}

A 63-year-old female natural from Imaruí, Imbituba municipality, southern coast of the Santa Catarina State was attended at the Hospital Universitário of Universidade Federal de Santa Catarina on January 2002. Reporting a former esophagus surgery, for which no records have been found, with no blood transfusion and a long-term dysphagia (>20years), the patient did not recognize triatomine bugs and affirmed that she had not traveled outside the Santa Catarina State. Indirect immunofluorescence (1:320) and ELISA

\footnotetext{
1. Departamento de Clínica Cirúrgica do Hospital Universitário da Universidade Federal de Santa Catarina, Florianópolis, SC. 2. Departamento de Microbiologia e Parasitologia da Universidade Federal de Santa Catarina, Florianópolis, SC, Brazil.

Address to: Dr. Edmundo C. Grisard. Dept ${ }^{\circ}$ Microbiologia e Parasitologia/UFSC. Caixa Postal 476, Trindade, 88040-900 Florianópolis, SC, Brasil.

Tel: 5548 331-9512; Fax: 5548 331-9258

e-mail: grisard@ccb.ufsc.br

Recebido para publicação em 24/5/2003

Aceito em 23/7/2003
} 
assays revealed positive and routine hemoculture was negative. Endoscopy and esophagogram showed stenosis of the distal portion of the esophagus and enlargement $( \pm 8 \mathrm{~cm})$ of the esophagus middle section (Figure 1). Examination of the lower digestive tract (colon), electrocardiogram, echocardiogram and thoracic X-ray revealed no alterations.

Prior to transhiatal esophagectomy and tissue sample collection for PCR, the patient voluntarily signed an informed consent, previously approved by the UFSC Ethics Committee.

During surgery, a sample of the enlarged portion of the esophagus was collected and fixed in $70 \%$ ethanol. Also, $10 \mathrm{~mL}$ of venous blood was collected with Vacutainer ${ }^{\circledR}$ system in tubes containing EDTA $\mathrm{Na}_{2}$
(Becton Dickinson, Franklin Lakes). Both samples were immediately submitted to DNA extraction.

DNA extraction and PCR amplification. DNA was obtained from esophagus and blood by phenolchloroform extraction according to standard protocols ${ }^{7}$. Prior to extraction, buffy coat was obtained from whole blood using Histopaque ${ }^{\circledR} 1077$ gradient (Sigma, St. Louis).

PCR was carried out using primers S-35 (5'- AAA TAA TGT ACG GGT GAG ATG CAT GA -3') and S-36 (5'- GGG TTC GAT TGG GGT TGG TGT -3') directed to $T$. cruzi kinetoplast minicircles ${ }^{12}$. After PCR amplification, products were resolved in $1 \%$ agarose gel electrophoresis, ethidium bromide stained and observed under UV light.

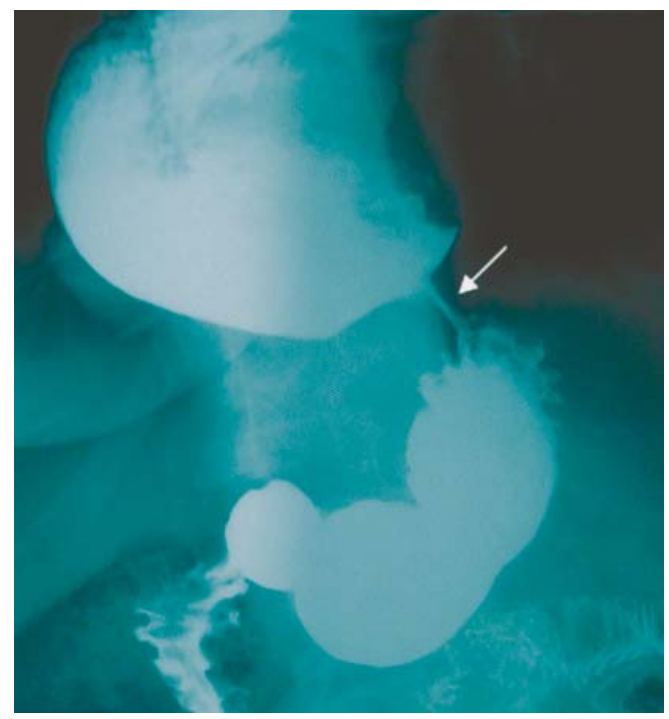

Figure 1 - Esophagogram of the patient showing a classic achalasia pattern. The enlarged esophagus blends into a smooth cone-shaped area of narrowing (arrow).

The patient was attended at the Hospital Universitário of UFSC reporting a long-term and progressive dysphagia (grade IV) ${ }^{6}$, with difficulty in swallowing dry food for the last 3 years with no regurgitation episodes. Anamnesis and clinical examinations lead to Chagas' disease diagnosis, which was confirmed by imaging and serological assays. Hemoculture in LIT medium was performed twice as previously described ${ }^{4}$, revealing negative results. Also, blood pressure, cardiac murmur and lower digestive tract exams were normal.
Natural from the State of Santa Catarina, the patient never had traveled outside the State and reported to have not undergone blood transfusion. Due to the nature of this autochthonous case, in that it is the first report of the digestive form of Chagas' disease in the State of Santa Catarina, further molecular diagnoses were performed.

During a successful corrective surgery, tissue samples were collected for molecular diagnosis and microscope examination. Both esophagus and buffy coat samples tested positive for T. cruzi, as indicated by the presence 
of a $330 \mathrm{bp}$ PCR product (Figure 2). Due the presence of T. rangeli in the Santa Catarina State ${ }^{3}$, DNA of $T$. rangeli SC-58 strain was included as control but no specific bands (760bp) were observed in the patient samples. Moreover, no cross-reaction of the primers S-35 and S-36 with human DNA was observed (Figure 2). Exam of the sample by microscopy discarded other possible etiologies.

Chagas' disease in Santa Catarina is mainly sylvatic and has a close correlation with opossums (Didelphis marsupialis) and Panstrongylus megistus, the most important local vector. Recent studies demonstrated that T. cruzi is found in $21.9 \%$ of the D. marsupialis captured in the Santa Catarina Island and in $45.2 \%$ of the same species captured in the Arvoredo Island, located $12 \mathrm{~km}$ north of the Santa Catarina Island ${ }^{2}$. These authors also demonstrated the presence of $T$. cruzi-infected P. megistus in human dwellings, revealing an infection rate of $55.3 \%{ }^{2}$.

Despite the existence of a sylvatic cycle of $T$. cruzi in the Santa Catarina State, the occurrence of human Chagas' disease is rare. Serological studies carried out in the Santa Catarina Island revealed only two autochthonous cases among 5,831 analyzed samples. Hemoculture was negative in both individuals ${ }^{1}$.

Studies on the trypomastigote morphology of $T$. cruzi strains isolated from triatomines and opossums in this state revealed the predominance of stout forms $(>70 \%)$ and medium virulence to mice as observed for strains isolated in the border State of Rio Grande do Sul ${ }^{8}$. These stout forms differ from the typical slender forms observed in endemic states such as Minas Gerais, where clinical Chagas' disease is a major public health problem. Former studies suggested a possible correlation between the parasite morphology and clinical-epidemiological aspects of the disease ${ }^{8}$.

Despite the observation of inferoposterior akinesia of the left ventricle during preoperative echocardiography,

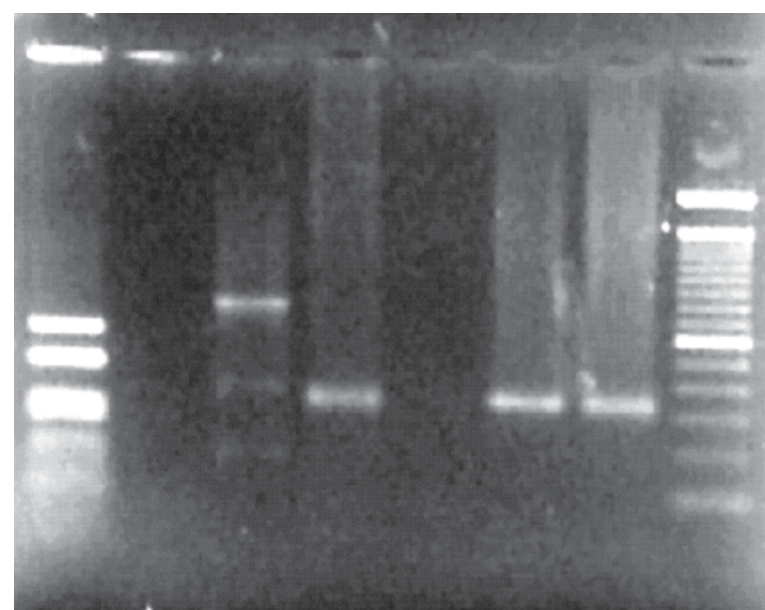

Figure 2 - Polymerase Chain Reaction (PCR) amplification of Trypanosoma cruzi $k D N A$ from the patient esophagus and buffy coat DNA samples using primers $S-35 / S-36$. Amplification products were resolved by electrophoresis through $1 \%$ agarose gel and visualized by ethidium bromide staining. LMW $=$ Low molecular weigh (pUC18 Haelll digested), NC= Negative control (no DNA added) TR DNA= Trypanosoma rangeli DNA, TC DNA= Trypanosoma cruz $D N A$, Human DNA=Non infected human buffy coat DNA, esophagus, buffy coat DNA from patient and 100bp DNA ladder (Promega, Madison).

cardiologic evaluation revealed to be normal. After surgery, the patient evolved with an atrial fibrillation and a right branch block, which was absent in the preoperative electrocardiogram.

Considering i) the epidemiology, ii) the results of the immunological and molecular methods described here, and iii) the absence of former reports of human Chagas' disease with digestive tract involvement, this is the first confirmed report of megaesophagus in the State of Santa Catarina caused by T. cruzi infection.

\section{REFERENCES}

1. Carobrez SG, Ishida MMI, Steindel M, Carvalho Pinto CJ, Grisard EC, Toma HK, Rosa R, Schlemper Jr BR. Investigation of the incidence of the human autochthonous chagasic infection in Santa Catarina Island, Santa Catarina State, Brazil. Memórias do Instituto Oswaldo Cruz 87 (supl II):220, 1992.

2. Grisard EC, Carvalho-Pinto CJ, Scholz AF, Toma HK, Schlemper Jr BR, Steindel M. Trypanosoma cruzi infection in Didelphis marsupialis in Santa Catarina and Arvoredo Islands, southern Brazil. Memórias do Instituto Oswaldo Cruz 95:795-800, 2000.

3. Grisard EC, Steindel M, Guarneri AA, Eger-Mangrich I, Campbell DA, Romanha AJ. Characterization of Trypanosoma rangeli strains isolated in Central and South America: An overview. Memórias do Instituto Oswaldo Cruz 94:203-209, 1999.

4. Luz ZM, Coutinho MG, Cancado JR, Krettli AU. Hemoculture: sensitive technique in the detection of Trypanosoma cruzi in chagasic patients in the chronic phase of Chagas' disease. Revista da Sociedade Brasileira de Medicina Tropical 27:143-148, 1994.

5. Nascimento HG, Vitorello DA, Schlemper Jr. BR. Estudo clínico dos primeiros casos autóctones da doença de Chagas em
Santa Catarina. In: Resumos do XXV Congresso da Sociedade Brasileira de Medicina Tropical, Florianópolis, p.170, 1989.

6. Rezende JM, Moreira H. Forma digestiva da doença de Chagas. In: Brener Z, Andrade Z, Barral-Neto M (eds) Trypanosoma cruzi e Doença de Chagas, 2nd edition, Guanabara Koogan, Rio de Janeiro, p. 297-343, 2000.

7. Sambrook J, Russel DW. Molecular Cloning: A Laboratory Manual. Cold Spring Harbour Laboratory Press, New York, 2001.

8. Schlemper Jr BR, Ishida MMI, Steindel M, Gargioni R. Very large trypomastigotes as a morphological pattern of strains of Trypanosoma cruzi in the southern region of Brazil. Memórias do Instituto Oswaldo Cruz 81:191-198, 1986.

9. Schlemper Jr BR, Piazza RMF, Garcia ACM. Soroepidemiologia da doença de Chagas em Santa Catarina. Revista da Sociedade Brasileira de Medicina Tropical 16:196-201, 1983.

10. Schmunis GA. Prevention of transfusional Trypanosoma cruzi infection in Latin America. Memórias do Instituto Oswaldo Cruz 94 (supl I): 93-101, 1999. 
11. Steindel M, Toma HK, Carvalho Pinto CJ, Grisard EC, Schlemper Jr. BR. Colonização de ecótopos artificiais pelo Panstrongylus megistus na Ilha de Santa Catarina, Florianópolis, Santa Catarina Brasil. Revista do Instituto de Medicina Tropical de São Paulo 36:43-50, 1994.

12. Vallejo GA, Guhl F, Chiari E, Macedo AM. Species specific detection of Trypanosoma cruzi and Trypanosoma rangeli in vector and mammalian hosts by polymerase chain reaction amplification of kinetoplast minicircle DNA. Acta Tropica 72: 203-212, 1999.

13. World Health Organization. Chagas' disease. Thirteenth Programme Report UNDP/WB/TDR, Genebra, p. 112-123, 1997. 